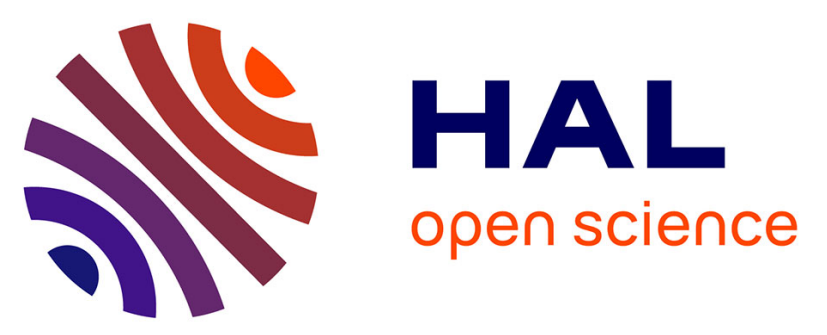

\title{
MICROSTRUCTURAL INVESTIGATIONS OF HIGH STRAIN RATE DEFORMED STEEL USING TRANSMISSION ELECTRON MICROSCOPY AND X-RAY LINE PROFILE ANALYSIS
}

\author{
F. Burgahn, O. Vöhringer, E. Macherauch
}

\section{To cite this version:}

F. Burgahn, O. Vöhringer, E. Macherauch. MICROSTRUCTURAL INVESTIGATIONS OF HIGH STRAIN RATE DEFORMED STEEL USING TRANSMISSION ELECTRON MICROSCOPY AND X-RAY LINE PROFILE ANALYSIS. Journal de Physique IV Proceedings, 1991, 01 (C3), pp.C3-291C3-296. 10.1051/jp4:1991341 . jpa-00250484

\author{
HAL Id: jpa-00250484 \\ https://hal.science/jpa-00250484
}

Submitted on 1 Jan 1991

HAL is a multi-disciplinary open access archive for the deposit and dissemination of scientific research documents, whether they are published or not. The documents may come from teaching and research institutions in France or abroad, or from public or private research centers.
L'archive ouverte pluridisciplinaire HAL, est destinée au dépôt et à la diffusion de documents scientifiques de niveau recherche, publiés ou non, émanant des établissements d'enseignement et de recherche français ou étrangers, des laboratoires publics ou privés. 


\author{
F. BURGAHN, O. VÖHRINGER and E. MACHERAUCH \\ Institut für Werkstoffkunde I. Universität Karlsruhe (TH), \\ D-7500 Karlsruhe, Germany
}

\title{
Résumé
}

Des études basées sur la microscopie électronique à transmission el l'analyse aux rayons $X$ ont été réalisées sur un acier au carbone $C_{k} 45$ (SAE 1045) initialement dans un état standard, pour caractériser l'influence de la vitesse de déformation et de la température sur la microstructure au delà de la déformation plastique.

Pour une déformation donnée on observe des variations caractéristiques du réseau des dislocations, lorsque la vitesse de chargement augmente, alors que les densités de dislocation restent inchangées. Des arrangements de dislocations tout à fait similaires se manifestent à température ambiante après une déformation à grande vitesse, et à basse température pour des vitesses de déformation relativement basses. L'analyse aux rayons $X$ met en évidence respectivement l'augmentation des déformations résiduelles et des contraintes résiduelles due au réarrangement des dislocations lorsque la vitesse de déformation croît, ou lorsque la température diminue.

\begin{abstract}
Investigations with transmission electron microscopy and $X$-ray line profile analysis on a plain carbon steel Ck 45 (SAE 1045) in a normalized state are carried out to characterize the influence of strain rate and temperature on the microstructure after plastic deformation.

With increasing strain rate at constant strain typical variations of the dislocation arrangements are observed, but the dislocation densities are not changed. Similar dislocation arrangements occur after high strain rate deformation at room temperature and low temperature deformation at low strain rates. Using the $X$-ray line profile analysis it becomes obvious that the internal microresidual strains and stresses, respectively, increase with increasing strain rate and decreasing temperature due to the dislocation arrangement.
\end{abstract}

\section{Introduction}

To characterize the microstructure of metals after plastic deformation as a function of strain rate and deformation temperature in addition to the transmission electron microscopy as well as the $X$-ray line profile analysis are used. The profile analysis allows to describe the structural defect structure of metallic materials in an integral manner, using deformation induced changes of the $\mathrm{X}$-ray interference line profiles. Appropiate properties determined by this method are the mean strain $\left\langle\varepsilon^{2}>1 / 2\right.$, which is proportional to the micro residual stress $\sigma \mathrm{micro}$, and the domain size $\mathrm{D}$ describing the size of coherent scattering regions. However, 
besides of the broadening of the interference line profiles by defects, the broadening is also caused by apparative effects. The determination of the physical true profile by separation of the instrumental broadening effects can be carried out by the single line (Voigt-) analysis /2/ and the multiple line analysis $/ 3,4$ / respectively. In cases of nearly homogeneous dislocation arrangements, the domain size $D$ and the mean strain $\langle\varepsilon 2>1 / 2$ allow the calculation of the total dislocation density $\rho_{\mathrm{t}}$, which agrees very well with $\rho_{\mathrm{t}}$ - values determined by the transmission electron microscopy $/ 5 /$.

\section{Experimental Details}

Compression tests were carried out at various strain rates $\varepsilon$ and deformation temperatures $T$ using the normalized steel CK 45 (SAE 1045) with the ferrite grain size of $8 \mu \mathrm{m}$ and the chemical composition in wt.-\% $0.47 \mathrm{C}, 0.3 \mathrm{SI}, 0.81 \mathrm{Mn}, 0.04 \mathrm{Cr}, 0.01 \mathrm{Mo}, 0.02 \mathrm{P}, 0.016 \mathrm{~S}$, and rest $\mathrm{Fe}$. The quasistatic experiments were carried out with $\dot{\varepsilon}=3 \cdot 10^{-3} \mathrm{~s}^{-1}$ up to distinguished deformations in the temperature range between $77 \mathrm{~K}$ and $423 \mathrm{~K}$. High dynamic compression tests up to $\varepsilon=10^{3} \mathrm{~s}^{-1}$ and $\mathrm{T}=298 \mathrm{~K}$ were performed using a Split-Hopkinson-Pressure bar. To calculate the characteristic parameters $D$ and $\left\langle\varepsilon^{2}\right\rangle 1 / 2$ using the Warren-Averbach method, the (110)- and the (220)-interference profiles were measured in the intervals 48.5-56.5 $\mathrm{O}_{2} \theta$ and $120-128 \mathrm{O}_{2} \theta$ using $\mathrm{CoK}_{\alpha}$-radiation with the stepsize of $0.02 \mathrm{O}_{2 \theta}$. To determine the total dislocation density $\rho_{t}$, the relationship

$$
\rho_{t}=\frac{2 \sqrt{3}}{b} \cdot \frac{\left\langle\varepsilon^{2}>1 / 2\right.}{D}
$$

was used $/ 5 /(b=$ amount of the Burgers vector $)$. Additionally transmission electron microscopy investigations were carried out to determine the dislocation arrangements and the dislocation density. For this purpose a transmission microscope (Hitachi $700 \mathrm{H}$, acceleration voltage $200 \mathrm{KV}$ ) was available. The dislocation density was estimated using the line intercept method of $/ 6 /$ with more than 30 micrographs of every test specimen.

\section{Experimental Results}

High strain rate deformation tests were carried out at $T=293 \mathrm{~K}$ to characterize the influence of the strain rate on the properties of the profile analysis. Fig. 1 shows the domain size $D$ and the mean strain $\left\langle\varepsilon^{2}>1 / 2\right.$ as a function of strain rate $\dot{\varepsilon}$ at constant strain $\varepsilon_{p}=5 \%$.

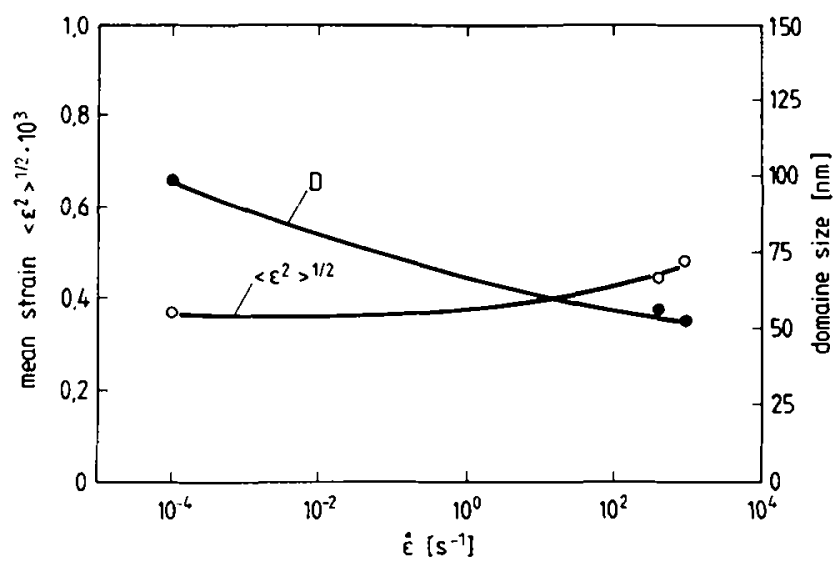

Fig. 1: Domain size $D$ and mean strain $\left\langle\varepsilon^{2}>1 / 2\right.$ as a function of strain rate $\dot{\varepsilon}$ at $T=293 \mathrm{~K}$ and $\varepsilon_{p}=5 \%$ 
With increasing strain rate the domain size $D$ decreases and the mean strain $\left\langle\varepsilon^{2}>1 / 2\right.$ increases. These changes are obviously caused by the high strain rate induced dislocation structure. While after quasistatic deformation the dislocation distribution is homogeneous or tangled and first signs of cell formation are observed (Fig. 2a), at high strain rates long straight-lying dislocations are found, which arrange in a more planar structure due to the reduced cross-slip ability (Fig. 2 b). This arrangement results in higher internal stress fields which correlate with the increase of the mean strain.

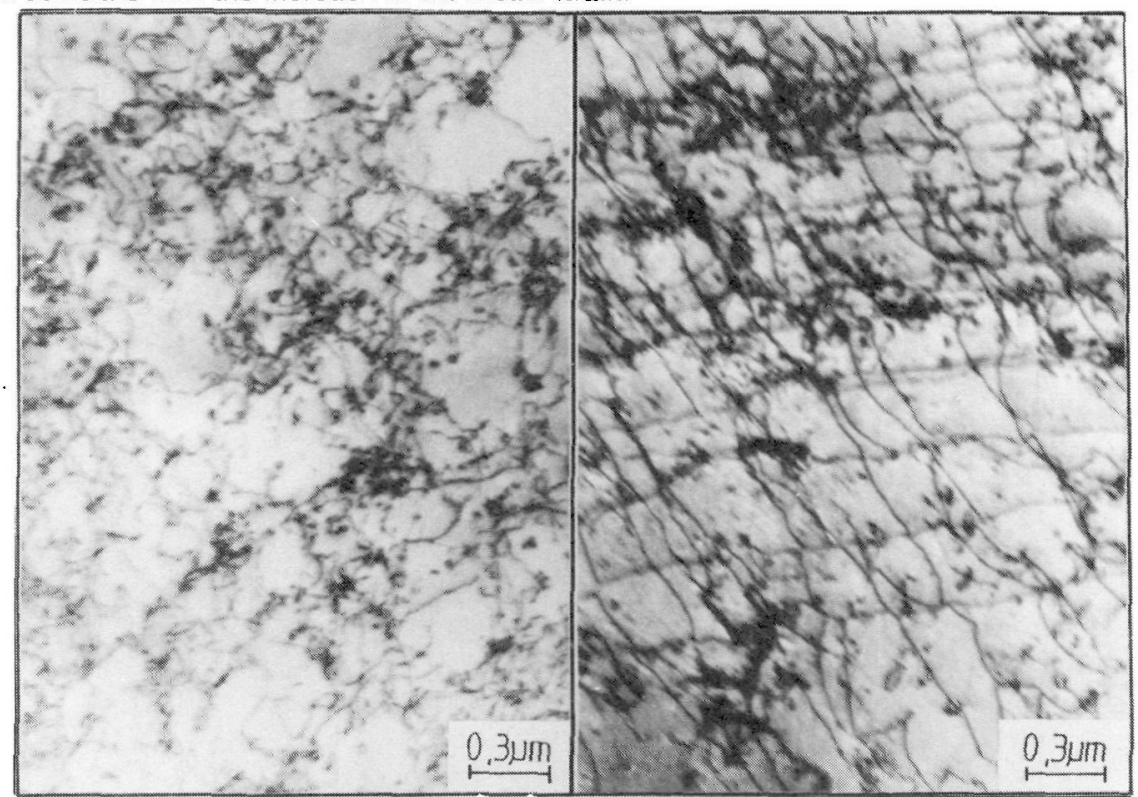

(a)

(b)

Fig. 2: Dislocation structures after quasistatic $\left(\varepsilon=3 \cdot 10^{-3} \mathrm{~s}^{-1}\right)(\mathrm{a})$ and dynamic deformation $\left(\dot{\varepsilon}=10^{3} \mathrm{~s}^{-1}\right)$ (b) at $\mathrm{T}=293 \mathrm{~K}$ and $\varepsilon p=5 \%$

At distinguished strain rates the dislocation density was determined with both the transmission electron microscopy and the $X$-ray line profile analysis using eq. (1).

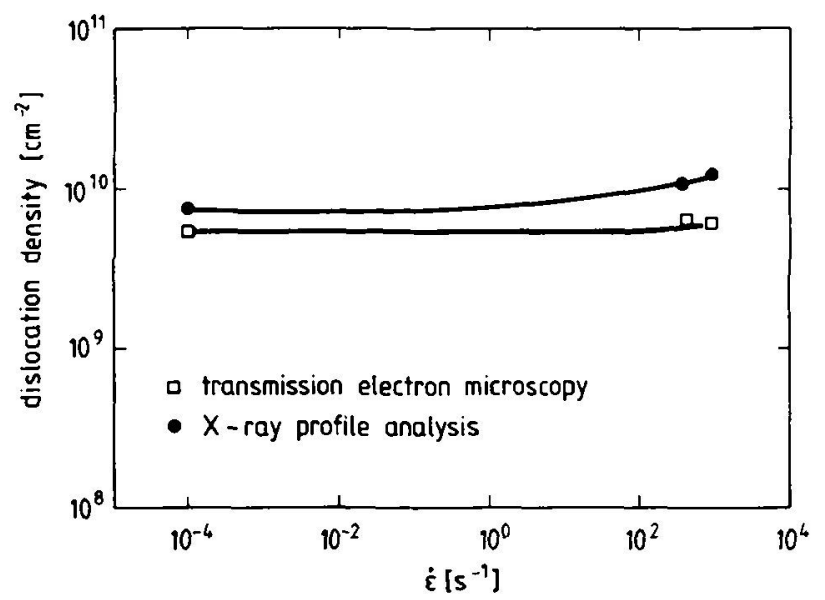

Fig. 3: Dislocation densitiy as a function of strain rate at $\varepsilon_{p}=5 \%$ and $T=298 \mathrm{~K}$, determined using transmission electron microscopy and $X$ - ray line profile analysis 
As presented in fig. 3 , at constant strain the dislocation density remains nearly uninfluenced by the strain rate. By both methods $\rho_{t}$ - values are determined, which show insignificant differences. The characteristic parameters of the $X$ - ray line profile analysis $D$ and $\langle\varepsilon 2>1 / 2$ are given in fig. 4 after quasistatic deformation as a function of deformation temperature. With decreasing temperature the domain size $D$ decreases (Fig. 4a).

(a)

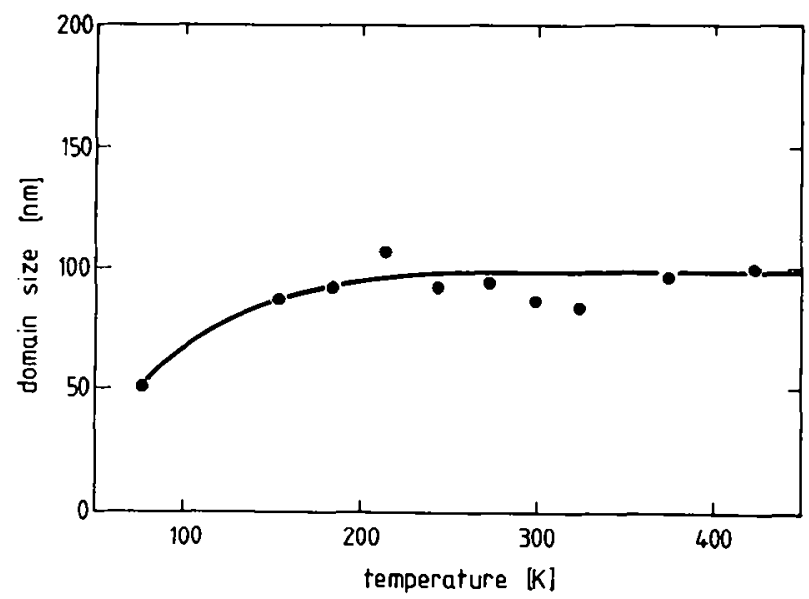

(b)

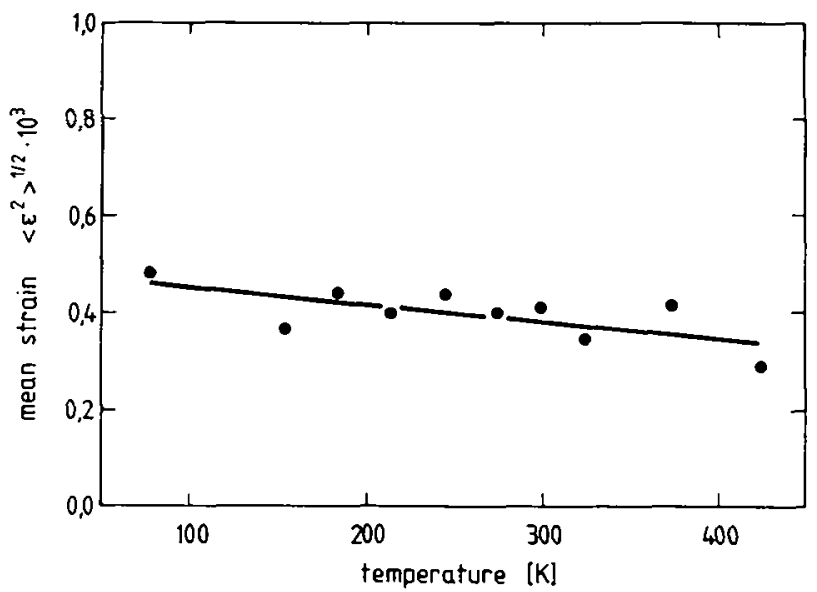

Fig. 4: Domain size (a) and mean strain $\left\langle\varepsilon^{2}>1 / 2\right.$ (b) as a function of the deformation temperature at constant strain $\varepsilon_{p}=5 \%$ and strain rate $\dot{\varepsilon}=3 \cdot 10^{-3} \mathrm{~s}^{-1}$

However, the mean strain $\left\langle\varepsilon^{2}>1 / 2\right.$ increases with decreasing temperature (Fig. $4 \mathrm{~b}$ ). These results, as shown by transmission electron microscopy investigations, are also connected with the trend to more planar dislocation structures due to the reduced possibility of cross-slip of screw dislocations at low temperature deformation (Fig. 5). Dislocation densities were determined in this case from both the transmission electron microscopy investigations and the profile analysis data, using eq. (1). Fig. 6 presents the results as a function of the deformation temperature at constant strain $\varepsilon_{p}=5 \%$. Again a good agreement between the values of the disiocation density, determined with both methods, is found. Moreover, $\rho_{t}$ is nearly indepen- 
dent of the deformation temperature.

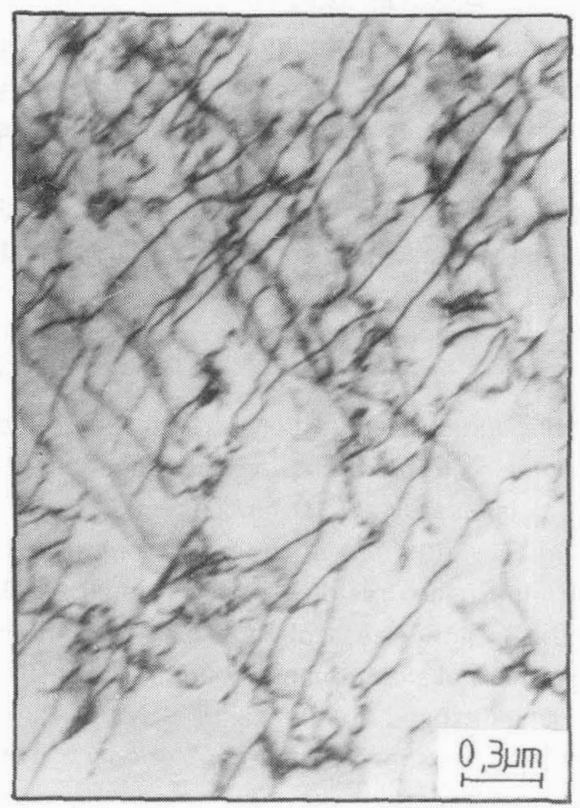

Fig. 5: Dislocation structure at $\mathrm{T}=77 \mathrm{~K}, \varepsilon_{p}=5 \%$ and $\varepsilon=3 \cdot 10^{-3} \mathrm{~s}^{-1}$

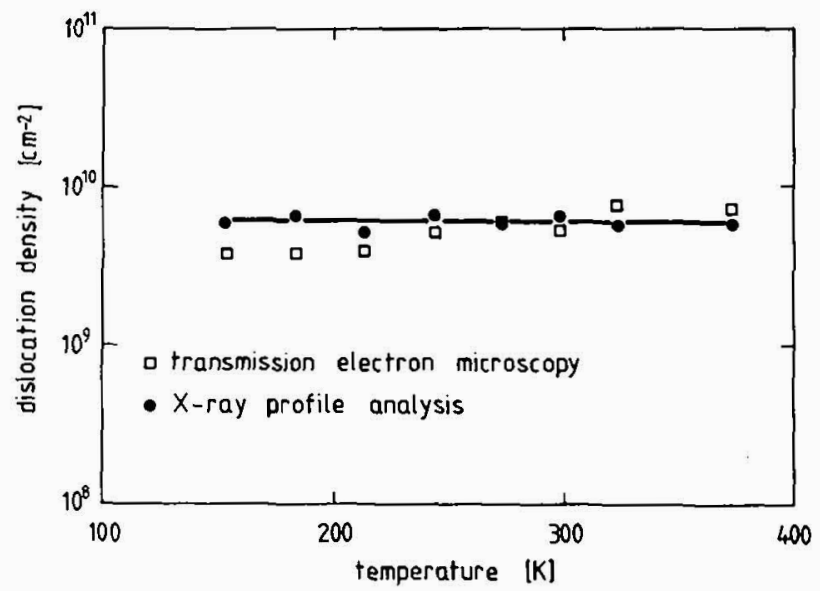

Fig. 6: Dislocation density as a function of deformation temperature, determined by transmission electron microscopy and $X$ - ray line profile analysis

\section{Discussion and Consequences}

Investigations on the plastically deformed normalized plain carbon steel CK 45 (SAE 1045) verify, that the $X$-ray line profile analysis yields to integral information on the behaviour of the 
microstructure. The calculated dislocation densities due to the characteristic parameters $\left\langle\varepsilon^{2}>1 / 2\right.$ and $D$ agree well with $\rho_{t}$ - values which are estimated with the transmission electron microscopy. Both methods exemplify, that the dislocation density seems not to be influenced by strain rate and deformation temperature. However, with increasing strain rate and decreasing temperature the dislocations exhibiting homogeneous and tangled arrangements at $\varepsilon_{p}=5 \%$ trend to lie more parallel (presumably screw dislocations). Therefore higher stress fields connected with higher internal energy are expected. These results agree with examinations of $/ 7,8,9 /$. As the mean strain obtained by the $X$ - ray line profile analysis is substantially determined from the residual stress fields of the dislocations considering the examined steel, the mean undirected residual stress can be estimated $/ 1 /$ by the relationship

$$
\sigma_{\text {micro }}^{r s}=E_{<h k l} \cdot<\varepsilon^{2}>1 / 2
$$

$E_{<} h k l>$ is Young's modulus which acts perpendicularey to the $X$ - ray measured lattice plane $\{h k l\}$. The changes of the dislocation microstructure induce the changes of the micro residual stresses. The amount of $\sigma$ micro is nearby $85 \mathrm{~N} / \mathrm{mm}^{2}$ using $E_{<220>}=220000$ $\mathrm{N} / \mathrm{mm}^{2}$. After high strain rate deformation $\left(\dot{\varepsilon}=10^{3} \mathrm{~s}^{-1}\right)$ at room temperature or quasistatic low temperature deformation $(T=77 \mathrm{~K}$ ) the micro residual stress is nearby $30 \%$ higher. Comparing the micro residual stress with the flow stress of SAE $1045\left(R_{p 5}\right.$ at $\left.\varepsilon_{p}=5 \%\right)$, which can be separated in a so-called athermal component $\sigma_{1}$ and a thermal component $\sigma^{*}(T, \dot{\varepsilon}) / 10 \%$, it is supposed, that $\sigma_{i}$ is influenced in the same way by the dislocation arrangement as $\sigma$ miscro. The ratio $\sigma_{i} / \sigma_{\text {micro }}^{r s}$ assumes a factor of about 4 . The distortion peaks which determine the "friction resistance" $\sigma_{j}$ of glide dislocations and the mean distortion of the dislocation network are relevant for this large factor. The distortion peaks as well as the mean values $\left\langle\varepsilon^{2}\right\rangle 1 / 2$ should increase with increasing strain rate and decreasing temperature respectively due to the observed changes of the dislocation structure. Therefore $\sigma_{i}$ is not constant at increasing $\varepsilon$, as usually assumed. In an analogous manner, at quasistatic low temperature deformation higher $\sigma_{i}$ - values are expected than those occuring at quasistatic deformation at room temperature.

\section{References}

11/ Wolfstieg, U.; Macherauch, E.: Eigenspannungen, DGM Informationsgesellschaft, Oberursel (1979), pp. 345-354

12/ Delhez, R.; De Kelyser, Th.H.; Mittemeijer, E.: Fres. Z. Anal. Chem. 3, 12 (1982), pp. 1-16

/3/ Warren, B.E.; Averbach, B.L.: J. Appl. Physics 21 (1950), pp. 595-599

14/ Warren, B.E.; Averbach, B.L.: J. Appl. Physics 23 (1952), p. 497

15/ Mikkola, D.E.; Cohen, J.B.: Met. Soc. Conf. 36 (Ed.: Cohen, Hilliard), Gordon and Breach Sci. Publ. (1965), pp. 289-330

/6/ Ham, R.K.: Phil. Mag. 6 (1961), pp. 1183-1184

/7/ Hornbogen, E.: Acta Met. 10 (1963), pp. 978-980

/8/ Ning, Ji: These de Doctorat, ENSAM 1989

19/ Cheval, F.; Priester, L.: Conf. Ser. Dymat 1988, Ajaccio 1988, pp. C 3-19

/10/ Burgahn, F.; Vöhringer, O.; Macherauch, E.: Proc. Shock-Wave and High Strain Rate Phenomena in Materials, Marcel Dekker (1991), in press 